\title{
In Search of Linguistic Terminology. System in Times of Symbol or Symbol for the Sake of System?
}

\section{Przemysław Lozowski}

Maria Curie Skłodowska University, Poland

p.lozowski@poczta.umcs.lublin.pl

\begin{abstract}
In the article we claim that scientific terminology should keep abreast of the times it serves. We identify the current intellectual climate as post-modernistic in the sense that general principles cannot be evaluated out of the spatiotemporal context in which they were initially proposed. Against that background the terminology of autonomous linguistics must be said to be no match for the present spirit of the times, while the terminology of non-autonomous linguistics lacks at times precision and common sense.
\end{abstract}

Keywords: terminology, definition, metaphor, symbol, system

Streszczenie

W poszukiwaniu terminologii językoznawczej: system w czasach symbolu czy symbol na potrzeby systemu?

Zakładamy, że terminologia naukowa powinna odzwierciedlać „ducha czasu”, tj. panujaca aure intelektualną. Te obecna określamy jako postmodernistyczna i identyfikujemy z poszukiwaniami subiektywności osadzonych $w i$ motywowanych przez kontekst doświadczeniowy człowieka. Stwierdzamy, że terminologia autonomicznych koncepcji języka rozmija się z obecnym ,duchem czasu”, a terminologia propozycji integracyjnych nie jest dostatecznie konsekwentna i przejrzysta.

Słowa kluczowe: terminologia, definicja, metafora, symbol, system

\section{Introduction}

In our work we would like to draw attention to two reasons why linguistic terminology may possibly hinder the perception of language studies. The first reason is related to the thesis that for something to be understood and to become familiar, it should be expressed in categories appropriate for the prevailing intellectual and cognitive climate, for the shared sensitivity and 
for the abiding mentality. In other words, if a description of a given phenomenon presented with the scientifically rigorous terminology encounters difficulties, resistance and opposition on the part of those it is addressed to, that is so because not only does it not match the cognitive experience of the receiver, but also it may actually be contrary to that experience. An attempt at organising the society according to the rules of theocracy in the times of democracy or designs on nationalisation in the era of privatisation are not just a misunderstanding, but also a threat. Talking and writing about language the way it is commonly done nowadays is not only anachronistic but also alarming.

The other reason why, in my opinion, linguistics presents didactic difficulties to us (linguists) and cognitive difficulties to them (students) is the fact that even when terminology does express the "zeitgeist", it still needs to do that in a consistent way, make clear references and stay in tune with common sense. In other words, the difficulty is that it is relatively easy to make an appearance of linguistic "zeitgeist", while, in reality, smuggling in the old conceptual apparatus by means of new terminology or dressing the new apparatus in the old terminology, in either case revealing the mentality of the previous epoch. This time, we could say that building "political capitalism" on the principle of nomenklatura buy-outs is still crypto-communism and public confessions of celebrities on what cosmetics they use most willingly is still product placement.

\section{Linguistic definition of language for our times}

Certainly, in order to be able to state what that anachronism or that danger consist in, one should first characterise that zeitgeist in which we happen to share our linguistic passions. I think that there is consensus about associating cognitive experience of modern humans with postmodernism, and defining the latter for example like Harvey does (1989; in Mairal, Gil 2006: 1):

The views that are presently most highly valued $[\ldots]$, are generally those that concede greater importance to particularism and fragmentation, focus on the individual nature and interest of the parts rather than the whole, and are ultimately conducive to the disarticulation or deconstruction of all human sociocultural and economic activities, [...] and affirm that there are no general principles that can be objectively evaluated independently of the spatiotemporal context in which they were initially proposed.

A similar thought is formulated by Szacki (1984: 10-12) and Furdal ([1990] 2000: 16-17), the former, while stating that we are witnessing the "revision [...] of the stereotype of traditional 
society $[\ldots]$ in the state of standstill and internal harmony", which results in tradition appearing as a "set of alternatives" and not a "system of values lacking cracks"; and the latter, when he "opens" linguistics to the voices from other branches of humanities:

The introduction of the concept of system into language studies [...] made the results of linguistic studies incomparably more precise. [...] Yet, this excellent [...] methodological recommendation carried the seeds of serious danger. [...] [I]solating facts of one type and searching for a structure among them $[\ldots]$ threatens $[\ldots]$ with research isolationism. $[\ldots][\mathrm{T}]$ hat is not a desired phenomenon. $[\ldots][W]$ e seem to have the right to call the times we are living in the onset of the era of the integration of science.

Therefore, if we were to prepare a description of language for our times, it should be saturated with notions such as deconstruction, individualism, individuality, partiality, purposefulness, relativity, subjectivity, contextuality, spatiotemporality, necessity, dynamism, localism and others, all of them being in opposition to such ideas as system, systemics, autonomy, modularity, structuralism, generating, deriving, etc.

\section{1. "Systemic" language of the English authors of introductions to linguistics}

It should be, but it is not. Even a superficial reading of the definitions of language, with regard to the terminology used, proves that the authors of introductions to linguistics tell a story detached from our reality or, at least, from our times. Fromkin et al. ([1998] 2010: 28), in what is probably the most popular introduction to linguistics in English, state that "language [...] is a system that combines sounds [...] with meanings. [...] Sounds and meanings [...] are connected arbitrarily." The term system never leaves the pages of this textbook - everything in language is a system, and the language itself appears to be a peculiar system of (sub)systems. And, in a system, on principle, there is nothing natural, nothing common-sensical, nothing that would have its cause and rational grounds for its existence except the self-regulatory and arbitrary mechanism of the system itself. Hence, the characterisation of language can be started with phonetics, led through phonology, morphology and syntax and completed with semantics (like in the first editions of the textbook), but (as in the more recent editions) it can start with morphology, go through syntax, then semantics, followed by phonetics, to finally crown the descriptive effort with phonology, or - like in a similar textbook by Akmajian et al. ([2001] 2010) endorsed by the Massachusetts Institute of Technology itself - start with morphology, go consecutively through the phonetic, phonological and syntactic systems to end with the semantic one. After all, in language as a system, people and their inclination to bring form and function 
together in a motivated way do not matter; what does matter is the relations, rules, and regulations, all of them generated by and derived from a brain of an abstracted and idealised speaker-listener, who, for the well-being of the unconstrained and effective description of the system, should best also be deaf and mute.

\section{2. "Systemic" language of the Polish authors of introductions to linguistics}

The language of the Polish introductions to linguistics is equally "systemic". Most of these textbooks clearly reflect the point of view worked out by Milewski (2004: 20), for whom language is a code (system of signs) of signals (signs both for the sender and for the receiver) which are semantic (signs refer to the phenomena from the world around us), arbitrary (signs which are linked with the content thanks to prior correlations), binary (signs whose number in the system is unlimited) and phonemic (signs whose form consists of phonemes). And so, Łuczyński and Maćkiewicz (2006: 17) define language as follows:

Language is a system of culturally transmitted, conventional signals (i.e. two-way signs: for the receiver and for the sender) the purpose of which is to communicate within a given community. It is a binary and semantic code, characterised by autonomy and creativity.

So, language is like Morse code - it constitutes a system of signs, each of them being an autonomous creation (or rather: projection) of rules assigning the elements of signals to the elements of information. Just like there is no rational explanation why in Morse code the letter $\mathrm{S}$ has the combination of three dots assigned to it, while $\mathrm{O}$ - the combination of three dashes, there is no rational explanation for the relationship between the form and the content in language. System - the key word in this definition - is a "set of elements organised in such a way that each element remains in a relationship with other elements and with the whole in which it has specific functions" (p. 11). There is no way the extra- and super-systemic parameters could decide about the way it is organised or about those functions. As Furdal says ([1990] 2000: 7172), "[the other most important feature of the language sign is] conventionality, known also as arbitrariness", which consists in that "the bond combining the content and the form of the sign is not justified by anything, which means there is no rationale behind it". Grzegorczykowa (2007: 24) adds this: "[Languages] are transmitted from generation to generation as systems of arbitrary signs in which there are no relationships between the form and the meaning".

We keep weaving our linguistic discourse invariably around the terms of the autonomous system of arbitrary signs, in which the speaker matters as much as a chess player matters in 
chess or a soldier in the army - all of them have to learn a closed system of rules and remain faithful and loyal to them till the end of their lives, as long as the first one wants to utter understandable phrases, the second - move the pieces on the board and the third one - live long enough to be promoted and retired.

\subsection{Extra- and super-systemic symbols}

So much for what is behind the closed doors and drawn curtains of linguistic workshops. What about outside them? Away from linguistics, the free world dismisses systems one after another, slowly forgetting that Europe used to resemble a chessboard of antagonised countries (like the opposition between the voiced /b/ and the voiceless /p/), that the Iron Curtain between the East and the West was as clear and as firm as the border between the linguistic form and content, between competence and performance, synchrony and diachrony or between the particular subsystems of language - phonetics and phonology, syntax and semantics, semantics and pragmatics, etc. Linguists seem to have missed the fact that while defining community identities, systemic oppositions have given way to shared symbolisations and conceptualisations, that the fact that Karol Wojtyła, Lhamo Thondup and Barack Obama are projections of their own systems (as John Paul II, the 14th Dalai Lama Tenzin Gyatso, and the 44th president of the United States, respectively) is less important than the functional super- and extra-systemic symbols they have projected of human aspirations and longings - for solidarity, freedom, equality and peace - and that, for many, marriage has ceased to be a binary relation of the malefemale type and it appears more and more often to be a completely extra-systemic symbol of a relationship between two humans.

And here we have it: in the times when systems crack up and various forms of selfawareness (national, racial, sexual, generational, cultural ones) wake up, a significant majority of linguists live in the times of the Berlin Wall and the Iron Curtain, conducting their analysis of language from such a "high" perspective that all they perceive in language is merely undisturbed harmony and order of a perfect system. Just like a pilot, who, through the window of his plane, sees the border between the land and the sea as a thick line separating two completely autonomous, isolated and fully balanced entities, even during the biggest squall or storm.

\subsection{Language as experience}


The majority of linguistics are like this, yet, not all. Beside and among linguistic "systemists", there is already quite a substantial group of teaching "symbolists" (functionalists, cognitivists). Instead of terminology appropriate for the description of language as a system of formal relations, they use the terminology adequate for characterising language as a symbol of human experience. For them, language is - or maybe I would like it to be - an unbridled element of human cognition, an archive of language users' memory and awareness, the resultant of cognitive tensions, the gauge of symbolisations of human experience which cannot be tamed, locked or constrained by any system, be it prescriptive or descriptive. Hence, the primary role of such terms as metaphor, polysemy, stereotype, prototype, empirical realism or cognition.

\section{5. "Symbolist" vs "systemic" linguistics}

Yet, as we said at the beginning, freeing linguistic terminology of the straightjacket of systemics, isolationism, modularity and wreathing it with the charm, allure and mystery of symbolisation is one thing, but doing it in a consistent, friendly, non-dogmatic, systematic, yet non-systemic way - is another thing. We have an impression that while "symbolist" linguistics is unquestionably more entrancing than the "systemic" one, because it expresses the mentality of modern people much better and follows the zeitgeist without inhibitions, it anyway gravitates towards terminology which soon, if not yet, will definitely limit its research horizons.

Here is one meaningful example from this field. Ronald Langacker, a leading cognitive linguist, has been repeating for years that "language is symbolic in nature and it makes available to the speaker - for their personal or communicative use - an open-ended set of linguistic signs or expressions, each of which associates a semantic representation of some kind with a phonological representation" (Langacker 1987: 11). What is more, as he adds, in the context of the functions of language and its biological, cognitive and sociocultural determinants, "cognitive and functional linguists find that virtually everything in language is motivated (even if very little is strictly predictable)" (Langacker 2008: 14). It might, then, be expected that the terminology applied will, to a significant extent, be deprived of arbitrariness and will have commonsensical motivation. But this is not so. Many terms do not correspond to what one may call the primary intuition of the language user and some are simply contrary to the instinctive understanding.

And so, for instance, Langacker's use of the term prototype (this time in compliance with the whole tradition of prototype theory) is such that this term does not stand for the expected meaning, that is, 'the first or preliminary example of a given category, from which all later forms are developed', but it denotes the best exemplar of the category. If we intuitively apply the term 
prototype in the search for, say, the proto-example of homo sapiens, this could be none of us as none of us does qualify to be the first or preliminary human being. Instead, the Neanderthal could, if we considered him/her the first thinking human. Similarly, if we follow the theory on the origin of birds, the archaeopteryx, a descendant of the theropod dinosaur, rather than a sparrow, a starling or a pigeon, must be claimed to be the prototype of the category of BIRDS. To repeat, for Langacker, the prototype stands not for the original representative of a category, but the most typical one. In this sense, neither of the two - the Neanderthal or the archaeopteryx, would he call a prototype of their corresponding categories.

What adds to the confusion here is another term Langacker correlates prototype with, that is, archetype: "the prototypical meaning consists of an experientially grounded conceptual archetype" (Langacker 2008: 34), archetypes being "experientially grounded concepts (...) frequent and fundamental in our everyday life" (p. 33), such as "physical object, an object in a location, an object moving through space, the human body, the human face, a whole and its parts (...)" (ibid.). In this (archetypical) context, "the conception of a physical object" is the archetype of/for nouns (p. 97). So, if ball, rather than orchard or air (pp. 35, 95), serves the purposes of the nominal prototype, this is because it complies with the archetype of an objective, physical, and discreteness entity in a more satisfying way than orchard and air do.

But, what, in fact, is this archetype all about? If for a noun to acquire the status of a best exemplar of its category (i.e. to be its prototype), it must denote an object that is physically real and distinct (i.e. to be archetypical), that means that archetypes have got to do with some absolutely basic, if not: schematic, characterisation that further on undergoes specific instantiations and elaborations in the form of less prototypical instances. In other words, prototypical amounts to 'most typical', and archetypical means 'most fundamental', both escaping one's intuitive judgement to understand one and the other in terms of 'being first/original/primary/primordial'.

Some cognitive effort is also needed in the case of two related terms: landmark and trajector. The main meaning of the former is 'a reference point', a 'breakthrough/milestone', which makes it play its primary role in a given context. For Langacker, though, landmark is only a secondary participant in a situation. In the sentence The lamp is above the table, it is not the lamp that is the landmark, though it might seem to us worthy of that term as a focal element of the situation, but the table. Intuitively, the lamp is a primary figure here (after all, this description is about the lamp, not about the table), but Langacker calls it a trajector, i.e. something that appears to be in motion along the orbit, or all around something else. Although the whole situation is static - the lamp is above the table, Langacker makes us see some virtual motion 
here. Having become acquainted with his arguments, we admit that he is right, yet, we cannot reach that understanding intuitively.

The arbitrariness of Langacker's terminology is sometimes associated with a bigger group of terms. For example, in his terminology there exists a play on words involving 3 related terms: ground, grounding and background. The first one appears with reference to figure, which implies a perceptual configuration known in psychology as the figure-ground arrangement. Langacker leaves no doubt as to the meaning of ground being 'background': "The term ground is used for the speaker and hearer, the speech event in which they participate, and their immediate circumstances (e.g. the time and place of speaking)" (2008: 78) and he gives examples: "a sudden noise stands out as figure against the ground of silence, or a small moving cursor against a more stable background on a computer screen" (2008: 58) . Both ground and background are evidently meant to be interchangeable.

Now, the situation gets complicated when Langacker introduces the foreground/background distinction (2008: 57): "Focusing [as a dimension of imagery] includes the selection of conceptual content for linguistic presentation, as well as its arrangement into what can broadly be described (metaphorically) as foreground vs background". This disturbs Langacker's intention of identifying ground with background, as above.

Even more complications concerning terminology vis-à-vis common sense are introduced by the term grounding, which, for Langacker, is related to ground, but not so much to background and foregrounding, and is understood as a relationship between the ground (a broader context of an expression) and a profile of a given expression with reference to cognitive domains. Grounding has to do with language being 'anchored', 'set' or 'grounded' in reality. Therefore, the expression boy like girl is not grounded, but the girl likes that boy or this girl may like some boy or some girl liked this boy are grounded thanks to the presence of grounding articles, pronouns, tenses, etc. As the very name suggests, grounding takes place in the ground. Should we want to follow closely Langacker's idea that ground is, in fact, background, we would need to interpret his example "a sudden noise stands out as figure against the ground of silence" in terms of noise being backgrounded in silence, which is not a desired import at all. ${ }^{1}$

${ }^{1}$ Some of these terminological quandaries come to the fore, or, to use Langacker's conception, are foregrounded, in the process of translation into other languages. And, thus, in Polish, figure-ground is given as figura-tło 'lit. figure-background'. Indeed, the term ground is rendered in the translations of Langacker's works as tło 'background', even though it is impossible to understand it this way without a context, because the primary meanings of ground are those of the 'surface of the earth', 'land', 'area', 'soil', and none of these invites background-related inferences. It may only be in peripheral references to painting and colouring that we can assume that ground means 'background' in the sense of a design appearing against some (back)ground. As dictionary definitions as well as common sense suggest that background should be translated as tho, this results 


\section{Conclusion - language as a symbol of human experience?}

In the face of the above discussions, a conclusion arises that there is a need for a consistent postmodernist definition of language as a symbol of human experience (not: a system of signs independent of how humans conceptualize the world) (cf. Łozowski 2015). One should not overestimate, though, the role of terminology in creating linguistic paradigms - experience shows that success and popularity of a linguistic theory are not determined by precise terminology, but by the genius of the research idea, always matching the contemporary times and always following the zeitgeist. It is hard to resist the impression that methodological proposals made by Saussure, Chomsky or Lakoff do demonstrate the intellectual climate of their times. Let us recall. On the eve of fear, chaos and horrors of World War I, Ferdinand de Saussure suggests absolute, ironclad and autonomous order of the synchronic (here and now) system and he dedicates the following warning to all those who would like to locate their research interests outside the system:

It is possible (...) to discuss whether the monogamous form of marriage is more reasonable than the polygamous form and to advance arguments to support either side. One could also argue about a system of symbols, for the symbol has a rational relationship with the thing signified (...); but language is a system of arbitrary signs and lacks the necessary basis, the solid grounds for discussion (...).

(Saussure 2011: 73)

Also Chomsky's thought to compare language to a generator or - as we would probably say today - to a computer, turned out undisputedly accurate. For him, to put it briefly, language is a hard drive (deep structure) from which the processor (transformations) generates an indefinite set of sentences on the monitor screen (surface structure). All that in mid-1950's, which is when first electronic computers were the size of huge wardrobes, if not whole rooms, and there was little to indicate that thinking in terms of drive-processor-monitor would one day completely capture our imagination! If Chomsky's generative view does not impress nowadays any more,

in two English terms ground and background rendered with the same Polish word tło. Hence the solution (in the Polish translations of Langacker) is to render ground as tło and background descriptively as plan dalszy/drugi (literally: 'further/secondary ground'). As to grounding, this term is translated into Polish as (za)kotwiczenie 'lit. anchoring', on the assumption that linguistic expressions are 'anchored' in reality. But that grounding takes place in the ground (Pol. tło 'background') is not easy to imagine because in Polish you cannot "ground" in the sense of 'anchor' anything in the "ground" in the sense of 'background' in any other than an arbitrary way. Instead of anchoring, we could perhaps translate grounding literally as 'set/kept in the ground', but then ground would have to mean 'earth, soil', and the examples of how Langacker understands ground do not allow for that. 
that is because perceiving anything (language included) in terms of the functioning of a computer seems so banal that it neither inspires nor arouses research curiosity. What does inspire and excite though is still Johnson and Lakoff's idea to see language as a big metaphor in which some (more abstract) domains of human existence are expressed by means of other (more specific) domains of human existence.

Time will show whether we shall ever decide to tell the students that language is simply a symbol of human experience, just like a wedding ring is a symbol of marriage, the scales are a symbol of justice and a white eagle is a symbol of Poland - and that language reflects the way human delights and phobias, truths and fantasies, dreams and phantoms, amazements and prejudices, hopes and despairs, beliefs and disbeliefs have been, are and will continue to be (cf. Łozowski 2008: 435).

\section{Acknowledgement}

This article was first published in Polish in 2012 in the volume entitled Termin $w$ językoznawstwie, Język a komunikacja 31, edited by Dorota Brzozowska and Władysław Chłopicki. Kraków: Tertium; 65-73.

Translation into English: Teresa Przyprawa

\section{References}

Akmajian, Adrian, Richard A. Demers, Ann K. Farmer, Robert M. Harnish ([2001] 2010) Linguistics. An Introduction to Language and Communication. Cambridge, MA: MIT. Fromkin, Victoria, Robert Rodman, Nina Hyams ([1998] 2010) An Introduction to Language. Boston: Wadsworth Publishing.

Furdal, Antoni ([1990] 2000) Językoznawstwo otwarte. Wrocław: Zakład Narodowy im. Ossolińskich.

Grzegorczykowa, Renata (2007) Wstęp do językoznawstwa. Warszawa: PWN.

Langacker, Ronald W. (1987) Foundations of Cognitive Grammar. Part 1: Theoretical

Prerequisites. Stanford: Stanford University Press.

Langacker, Ronald W. (2008) Cognitive Grammar: A Basic Introduction. Oxford: Oxford University Press.

Łozowski, Przemysław (2006) „Podobieństwo jako przejaw niedowolności (niearbitralności) 
znaku językowego”. [In:] Henryk Kardela, Zbysław Muszyński, Maciej Rajewski (eds.) Podobieństwo. RRR Kognitywistyka 2. Lublin: Wydawnictwo UMCS; 131-142.

Łozowski, Przemysław (2008) „Od dziecka do człowieka, czyli ‘być mężczyzną’ w słownikach”. [In:] Andrzej Radomski, Bogumiła Truchlińska (eds.) Męskość w kulturze współczesnej. Lublin: Wydawnictwo UMCS; 428-435.

Łozowski, Przemysław (2011) „Tradycja jako panchronia, czyli w poszukiwaniu ciągłości kultury". [In:] Jan Adamowski, Marta Wójcicka (eds.) Tradycja dla wspótczesności. Vol. 4. Lublin: Wydawnictwo UMCS; 113-123.

Łozowski, Przemysław (2015) „Dialog doświadczenia z tradycją: postmodernizm na barykadach modernizmu". [In:] Renata Dźwigoł, Iwona Steczko (eds.) Dialog z Tradycja: język - komunikacja - kultura. Vol. III. Kraków: Collegium Columbinum; 47-55.

Łuczyński Edward, Jolanta Maćkiewicz ([2001] 2006) Językoznawstwo ogólne. Wybrane zagadnienia. Gdańsk: Wydawnictwo Uniwersytetu Gdańskiego.

Mairal, Ricardo, Juana Gil (2006) ”A First Look at Universals”. [In:] Ricardo Mairal, Juana Gil (eds.) Linguistic Universals. Cambridge: Cambridge University Press; 1-45.

Milewski, Tadeusz ([1965] 2004) Językoznawstwo. Warszawa: Wydawnictwo Naukowe PWN.

Saussure, de Ferdinand ([1911] 2011) Course in General Linguistics. [Cours de linguistique générale. Paris: Editions Payot \& Rivages]. Translated by Wade Baskin. New York: Columbia University Press.

Szacki, Jerzy (1984) „Słowo wstępne”. [In:] Jerzy Szacki (ed.) Tradycja i nowoczesność. Warszawa: Czytelnik; 5-13.

Yule, George ([1985] 2010) The Study of Language. Cambridge: Cambridge University Press. 